\title{
Dzieje innych miłości, czyli o nieprzekładalności bezwzględnej w tekstach o wartościach w sztuce
}

\author{
Teresa Bałuk-Ulewiczowa \\ Uniwersytet Jagielloński w Krakowie \\ baluk.ulewiczowa@gmail.com
}

\begin{abstract}
Streszczenie
Autorka stawia pytanie o nieprzektadalność „absolutna”, czyli o to, co nie dociera do obcojęzycznego odbiorcy translacji. Na podstawie albumu o zabytkach kultury polskiej przechowywanych $w$ Bibliotece Narodowej $w$ Warszawie, $w$ wersji angielskiej thumaczonej $z$ polskiego oryginatu $i$ mogacej stużyć za wzór znakomitego przekładu, ukazuje, jak teksty odnoszace się do sztuki narodowej moga zawierać takie pułapki dla tlumacza. Mimo doskonatego wykonania przekładu, $u$ docelowego odbiorcy z innego kręu kulturowego tlumaczenie nie wywotuje tych samych reakcji na specyficzne, inherentne wartości tekstu pierwotnego, doznawanych przez czytelników należacych do społeczności kulturowej tekstu wyjściowego.
\end{abstract}

Słowa kluczowe: nieprzekładalność absolutna, tłumaczenie, odbiorca docelowy, tekst wyjściowy, tekst o sztuce

Abstract

A Different Love Story: Some Remarks on "Absolute" Untranslatability in Texts on Values in the Arts

The author asks whether there is such a thing as "absolute" untranslatability. In other words, do situations occur in which the full translatability of a text is prevented no matter how good the translation and how skilful the translator? She examines the English translation of a volume on national heirlooms, items of Polish heritage preserved in the National Library in Warsaw. This translation may be regarded as a benchmark for quality, yet it turns out that recipients not belonging to the Polish cultural milieu will not be able to respond emotionally in the same way as natives to the cultural values inherent in the original text.

Keywords: absolute untranslatability, translation, target recipients, original text, text on art 


\section{Wstęp}

W niniejszej analizie interesuje nas pytanie o granice przekładalności: czy istnieje nieprzekraczalna bariera, uniemożliwiająca skuteczny przekaz w przekładzie niektórych elementów tekstu? Czy istnieje coś, co można by nazwać nieprzekładalnością bezwzględną (absolutną, „głęboką”, nieusuwalną) - nie w sensie ilościowym (czyli w znaczeniu bariery uniemożliwiającej przekład w ogóle jako całości), ale w sensie jakościowym (zapory blokującej skuteczny przekaz pewnych istotnych składników tekstu)?

\section{Badania nad nieprzekładalnością}

Dotychczasowe badania nieprzekładalności opierały się głównie o kategoryzację na:
1) nieprzekładalność językową,
2) nieprzekładalność kulturową.

Przez nieprzekładalność językową (linguistic untranslatability) rozumie się problemy z przekładalnością, wynikające z przyczyn językowych. Na podstawie własnej praktyki, uważam że ostatecznie nieprzekraczalną barierę w translacji stanowi nieprzekładalność kulturowa, choć niekoniecznie każdy jej przypadek. Jeśli w pojęciu kultury uwzględnimy zjawisko doświadczenia zbiorowego - świadomości kształtowanej w jednostce dzięki jej uczestnictwu w życiu i zbiorowych doświadczeniach konkretnej grupy społecznej - wówczas możemy mówić o tekstach zawierających elementy nieprzekładalności bezwzględnej. Chodzi tu o świadomość i doświadczenia emocjonalne, powstałe i narastające w konkretnych warunkach historycznych, w jakich przyszło żyć danej społeczności, nieznanych zaś, bo nieprzeżywanych, w innych społecznościach. Społecznością taką może być naród, ale także i mniejsza grupa. Kiedy zachodzi potrzeba przekładania tekstów powstałych w obrębie takiej grupy na język, w którym żadna z posługujących się nim grup nie wytworzyła podobnych odniesień socjolingwistycznych na skutek braku zbiorowych doświadczeń historyczno-kulturowych analogicznych do tych zawartych w pozasemantycznej warstwie tekstu do przekładu - wówczas w translacji występują trudności nie do rozwiązania, czyli nieprzekładalność bezwzględna.

Praktyka zawodowa przekładu z języka polskiego na angielski znakomicie ilustruje zjawisko nieprzekładalności bezwzględnej rozumianej w ten sposób. Często jednak strony bezpośrednio zainteresowane przekładem, nierzadko nawet sami tłumacze, nie zdają sobie sprawy $\mathrm{z}$ istnienia przeszkód tego typu w pełnym przekazie treści wyrażonej pierwotnie $\mathrm{w}$ 
języku A w przekładzie na język B, obwiniając siebie samych za rzekome braki warsztatowe, gdy wyniki tłumaczenia zawodzą ich oczekiwania.

\subsection{Nieprzekladalność bezwzględna w tekstach o sztukach pięknych}

Jedną z dziedzin, w której często występują przypadki nieprzekładalności tego typu, stanowią teksty o sztukach pięknych, wraz z zawartymi w nich rozmaitymi systemami wartościowania estetycznego. Zakres to nie tylko ciekawy, lecz także trudny, a przede wszystkim coraz częściej pojawiający się w prestiżowych tekstach o kulturze polskiej, zlecanych tłumaczom przez znaczące instytucje.

Zdawać by się mogło, że sztuki plastyczne, operujące przecież uniwersalnymi środkami formy, barwy, kształtu, faktury, obrazu i kompozycji przestrzennej - przekazują treści uniwersalne, podlegające powszechnie uznawanym sposobom opisu werbalnego. Jednak obok uniwersalizmu, w sztukach pięknych występuje także niezliczony makrokosmos rozmaitych wyobrażeń partykularystycznych, podlegających interpretacji determinowanej przez właściwą im kulturę. Wokół konkretnych obrazów bądź zbiorów ikonograficznych, specyficznych dla danej kultury, narastają także i określone formy i środki ekspresji retoryczno-werbalnej w języku właściwym dla ich kultury macierzystej. Systemy aksjologiczne, występujące w twórczości artystycznej, a także ich odbicie językowe w tekstach o sztuce - różnią się w zależności od tradycji w danej kulturze. Według Jana Białostockiego:

obok wartości ponadczasowych, ponadnarodowych, ogólnoludzkich, są też przedmioty o wartości osobistej (...) jak np. przedmiot, który należał do rodziców, fotografie dziecka (....), krajobrazy, do których przywykliśmy (...). [Ale również] są rzeczy cenne dla szerszej grupy ludzi - dla starszych mieszkańców Warszawy cenny jest jej wygląd zapamiętany sprzed wojennego zniszczenia, cenne są zabytki i pamiątki lokalne, często zupełnie niskiej miary pod względem znaczenia artystycznego. Dla grupy narodowej wartościowe są pamiątki istnienia świadczące o znaczeniu, dawności, spójności tej grupy. Owe Monumenta Sarmatarum czy Monuments de la Monarchie Française doceniano i publikowano już w XVII i XVIII wieku. W tej kategorii mieści się też wysoka ocena ludzi szczególnie zasłużonych dla bytu narodowego - działaczy i bohaterów (Białostocki 1988: 9).

W tekstach opisujących sztukę narodową nieuchronnie pojawiają się momenty nieprzekładalności bezwzględnej, której podlegają zwłaszcza fragmenty zawierające kategorie wartościujące według klucza kultury rodzimej dla danej tradycji artystycznej. 
W grudniu 2000 r. Biblioteka Narodowa w Warszawie wydała w wersji zarówno anglojęzycznej, jak i polskiej pamiątkowy album pt. Nad złoto droższe. Skarby Biblioteki Narodowej (More Precious Than Gold. Treasures of the Polish National Library), składający się z fotografii i opisów 105 najcenniejszych zabytków kultury spośród swych kolekcji. Jak już sam tytuł wskazuje, kwestie wartościowania estetycznego odgrywają tu rolę pierwszo-planową. W jaki sposób zostały owe wartości odzwierciedlone w przekładzie? Oto co na promocji albumu powiedział Janusz Tazbir, przeczuwając trudności wynikające z pułapek czekających na Tłumacza:

Nie miałem jeszcze w ręku angielskiej wersji tego albumu i nie wiem, czy jest opracowana tak samo jak polska. Moim zdaniem, wymagałaby innej kompozycji. Wstępy do takich dzieł pisane są za pomocą swoistego narodowego szyfru. (...) A jak wytłumaczyć Anglikowi, że w okresie walki o niepodległość z książek budowano, dosłownie i w przenośni, barykady, że na księgozbiorach mścili się zaborcy i mścili się zwycięzcy, że równie nie szanowano manuskryptów, jak nie szanowano szpitali powstańczych, że dzieje książki splatały się nierozerwalnie z dziejami narodu, który miał to nieszczęście, że toczył walkę o swoją niepodległość na zgliszczach bibliotek (Tazbir 2000: 47).

Zadaniem Tłumacza było dokonanie przekładu, a nie “opracowanie innej kompozycji”, choć jak słusznie przewidywał Recenzent, w wersji obcojęzycznej należało opowiedzieć tę historię „inaczej”. Co tylko wskazuje na jej zasadniczą nieprzekładalność... Zgodnie z diagnozą Białostockiego, okazuje się, że wśród wypowiedzi określających wartości opisywanych zabytków, ciągle przewijają się kryteria walorów dzieł ocalałych z dawnych zbiorów BN jako „pamiątek istnienia, świadczących o znaczeniu, dawności, spójności” wielu pokoleń należących do kultury polskiej i wzbogacających jej spuściznę. Wartości te widać już we Wstępie (pióra Michała Jagiełły):

Dobry los sprawił, że mogę otwierać ten niezwykły album zaproszeniem do lektury i refleksji nad trwałością i urodą słowa, losami książek i bibliotek, a tym samym nad dziejami ludzi i narodów, państw i systemów politycznych. Taka refleksja jest zawsze pożyteczna. A są sytuacje, w których jest wręcz niezbędna. Zwłaszcza nam, obywatelom Rzeczypospolitej Polskiej, i zwłaszcza dziś, u progu trzeciego tysiąclecia. Stajemy przecież wobec obowiązku ponownego zdefiniowania starych, zdawałoby się, oczywistych pojęć, jak „patriotyzm”, „suwerenność państwowa”, „tradycja” i zarazem wobec konieczności przyswojenia sobie idei zupelnie nowych, tych, które łączą się z praktyczną realizacją koncepcji zjednoczonej Europy.

Namysł nad zachowanymi do naszych czasów skarbami polskiej i europejskiej kultury, także nad dziełami okaleczonymi przez czas i przez szaleństwa wojen, a nawet nad popiołami 
książek i ich cieniami, jest naszym obowiązkiem nie tylko wobec przeszłości, lecz przede wszystkim wobec dnia dzisiejszego i wobec przyszłości.

Biblioteki są szczególnym miejscem kultury. W pieczołowicie przechowywanych książkach zmaterializowana jest ciągłość, zatem biblioteki, to żywe pomniki pamięci (TchórzewskaKabata 2000:5).

A co dzieje się $\mathrm{z}$ przesłaniem emocjonalnym tego tekstu $\mathrm{w}$ angielskim przekładzie wykonanym zresztą na bardzo wysokim poziomie technicznie? Proszę mnie właściwie zrozumieć: traktuję tu umiejętności translatorskie Janiny Dorosz i Philipa E. Steele'a jako znakomite, z tzw. „najwyższej półki”, a dokonane przez Nich tłumaczenie mam za modelowe. I dopiero na takiej podstawie badam, czego nie udało się oddać w przekładzie nawet tak znakomitym Tłumaczom.

Zupełnie inną wymowę, kameralną i swojską, ma zwrot „nam obywatelom Rzeczypospolitej Polskiej” - wypowiedziany w języku polskim i do Polaków; zupełnie inną deklaratywne „for us, citizens of the Polish Republic”. Inne zaplecze uczuciowo-konotatywne zarysowuje się za terminami „patriotism”, „state sovereignty”, „tradition”, które mogą być „such old and seemingly self-evident concepts” na sposób zgoła odmienny niż ich semantycznie dokładny pierwowzór w tekście polskim. Inne doświadczenia dziejowe kryją się za angielskim „the folly of war” (nota bene zwrot w liczbie pojedynczej: „obłęd wojny”), niż w polskim zwrocie „szaleństwa wojen” interpretacyjnie zakorzenionym w polskim doświadczeniu zawieruchy wojennej, bycia ofiarą a nie sprawcą jej zniszczeń. Trudno się dziwić, że inaczej na płaszczyźnie emocjonalnej odbierane są angielskie „durability” i „continuity”, inaczej zaś polskie - „trwałość” i „ciągłość”; oraz zwrot „monuments to living memory” i niemal przeciwstawne mu ,żywe pomniki pamięci” - sugerujące także i fakt bezpowrotnej utraty innych, co najmniej równie cennych zabytków, przypominanych w tym albumie pośrednio poprzez hołd składany tym ocalałym. W semantycznie wiernym tłumaczeniu tych słów próżno by się doszukiwać tych samych emocji, związanych z osobiście poniesioną, a zarazem zbiorową stratą. Choć wyrażona w płaszczyźnie semantycznej, w angielskiej wersji jawi się ona jako strata i krzywda obca, cudza, odległa.

Tłumacze stosują ciekawy zabieg, usiłując zrekompensować niemożliwość pełnego oddania zawartości emocjonalnej wyrażenia o książkach „pieczołowicie przechowywanych”. Rezygnując z semantycznej ekwiwalencji, zastępują ten zwrot sformułowaniem „books attended to with loving care". Substytucja ta jednak tylko częściowo odtwarza uczucia, które w 
świadomości polskich odbiorców wiążą się z pojęciem pieczołowitego przechowywania skarbów kultury rodzimej w obliczu groźby zagłady.

A przynajmniej tak było ,po angielsku” do 11 września 2001r. ...

Wśród wartości wyliczanych w opisie zabytków BN często występuje motyw patriotyzmu. Pojawia się nawet w relacjach faktograficznych - poprzez dobór słownictwa nacechowanego emocjonalnie:

„Rękopis ten, zagrabiony przez okupanta niemieckiego w listopadzie 1939 roku (...)” (TchórzewskaKabata 2000: 38).

Tłumacze, zapewne wyczuwając bezsens przekładu o podobnym stopniu emocjonalności, wprowadzili spokojniejszą formułę, wraz w wiadomym złagodzeniem w duchu zachodniego political correctness:

„This manuscript, stolen by the Nazi invaders” (Tchórzewska-Kabata 2000: 38A).

Wątek patriotyczny wzmacniają ciągle powracające uwagi o bezcenności tego, co ocalało:

„Tego jednak, co spalono, co w czasie wojny zniszczało, nikt i nic już nie przywróci. Niekiedy tylko zdarzają się cudowne niemal zmartwychwstania dzieł zdawałoby się bezpowrotnie straconych, a odnajdywanych po latach" (Tchórzewska-Kabata 2000: 12).

Dziwnie jakoś nie na miejscu w przekładzie relacji faktograficznej, nawet ironicznie, brzmią zwroty takie, jak „Miraculous resurrections of works believed to have been irretrievably lost are very rare" (Tchórzewska-Kabata 2000: 14A).

Kolejne ślady nieprzekładalności w tym albumie, wynikające z odmienności systemów wartościowania, dotyczą wątku znanego na całym świecie: „poety i jego muzy” skonkretyzowanego tu aż trzy razy, w opisach trzech różnych zabytków kultury materialnej, związanych z trzema różnymi poetami polskimi oraz ich wybrankami. Mickiewicz i Maryla, Baczyński i jego Basieńka, Norwid-samotnik - trzy epizody z historii literatury polskiej, wręcz z mitologii narodowej - a dla Tłumaczy gąszcz problemów nie do rozwiązania.

Cóż bardziej ogólnoludzkiego, przemawiającego z taką samą intensywnością uczuć do każdego bez względu na jego zaplecze kulturowe, jak historia miłosna? - Okazuje się jednak, 
że niektóre historie miłosne zakotwiczone są tak głęboko w swojej kulturze macierzystej, że zupełnie co innego znaczą dla odbiorcy rodzimego, a co innego dla obcych. Inaczej nie-Polacy odbierają na płaszczyźnie emocji dzieje uczuć naszego Wieszcza do Maryli, niż dzieci od kolebki wychowane w kraju, w kulturze tworzącej właściwą glebę opowieści o Adamie i Maryli. Zupełnie inaczej reagują na historię bliską własnej tradycji domowej i szkolnej, mając przed oczyma podobiznę karty tytułowej konkretnego egzemplarza Sonetów z dedykacją swojej muzie domowej, niż odczuje to nawet najlepiej przygotowany polonista nie-Polak. Ileż treści owych emocji utracono w przekładzie zdania:

(...) tę właśnie książkę Mickiewicz przesłał Maryli Wereszczakównie, wówczas już Putkamerowej, swej wielkiej młodzieńczej miłości i zarazem najbardziej znanej, dzięki niemu, muzie polskiego romantyzmu. Uczuć poety nie ujawniała lapidarnie brzmiąca dedykacja: „Maryi Putkamerowej Adam Mickiewicz. Moskwa 1827, Stycznia 2. - (Tchórzewska-Kabata 2000: 190).

(...) this is the very book which Mickiewicz sent to Maryla Wereszczakówna, by then Mrs. Puttkamer, his first love and, thanks to him, the best known muse of Polish Romanticism. The brief dedication, 'Maryi Putkamer (?)[!!!] Adam Mickiewicz. Moskwa 1827, Stycznia 2' [To Maria Putkamer from Adam Mickiewicz. Moscow 1827. January 2] does not reveal the poet's feelings. (Tchórzewska-Kabata 2000: 190A).

Bezradność Tłumaczy wobec dylematu, jak rozwiązać problem wiele mówiących tu końcówek -ówna/-owa, tudzież staroświeckiej ortografii imienia „Marya” (pomijając sprawę ich niepotrzebnie zmodyfikowanej transkrypcji, czyli błędnie i zupełnie myląco dokumentacyjnie, wobec form faktycznych, reprodukowanych obok na zdjęciu) - wynika z problemu nieprzekładalności o wiele bardziej skomplikowanej, niż prosta przeszkoda językowa. Wydaje się, że w przeciwieństwie do wspomnianej tezy, jakoby ostateczne trudności w translacji sprowadzały się do nieprzekładalności językowej - w rzeczywistości bywa całkiem na odwrót. Językowe bariery w przekładzie okazują się często (a może z zasady?) tylko powierzchownymi, incydentalnymi, ale za to oczywistymi i namacalnymi skutkami problemów tkwiących w samej istocie translacji - odmienności kultur na poziomie zbiorowych doświadczeń historycznych wychowanych i uczestniczących w nich społeczeństw.

W analogiczny sposób zaprzepaszczono emocjonalną wymowę słów - a zwłaszcza zdrobniałej formy imienia - na karteczce Baczyńskiego:

mojej kochanej Basieńce w dniu naszego ślubu 
Oddano ten napis jako:

To my beloved Babs on our wedding day - Krzysztof. June $3^{\text {rd }}$, 1942. (Tchórzewska-Kabata 2000: 236A).

Nie tylko nie odtworzono wartości zdrobnienia („Babs” odpowiada jakiejś „Baścechłopczycy"), ale ostatecznie zablokowano niepolskiemu odbiorcy możliwość choćby częściowego dostępu do tego i tak niepoddającego się próbom przekładu mitu z epopei bohaterskiej Warszawy. I tutaj teoria nieprzekładalności językowej sprowadza się do bariery kulturowej.

Wreszcie enigmatyczne uczucie Norwida, uzewnętrznione przez ulotną chwilę w rysunku zatytułowanym Sen skazańca, co oddano jako The Convict's Dream - mimo, że nad obrazkiem widnieje napis w języku francuskim: „rève d'un captif”, zacytowany zresztą w tekście opisu i figurujący tam jako „A captive's dream”. Lecz nawet jego powtórzenie w tytule i tak nie pozwoliłoby na pełny przekaz kłębowiska kryjących się w micie norwidowskim uczuć, czytelnych w pełni tylko w doświadczeniowym kontekście kultury polskiej.

W przekładzie opisów tych polskich historii miłosnych zabrakło właśnie tego, co tkwi w ich warstwie pozaleksykalnej, lecz czytelnie dla polskiego odbiorcy - niezbędnego tła zbiorowych przeżyć patriotyczno-narodowych.

\section{Wnioski}

W tekstach o podobnej problematyce tezę o nieprzekładalności możemy przepisać W następujący sposób:

Ostateczną barierę w przekładalności stanowią rozbieżności kulturowe na poziomie głębokich, emocjonalnych doświadczeń zbiorowych, dzielących społeczność tekstu wyjściowego od społeczności jego przekładu.

\section{Źródło}

Tekst ten został po raz pierwszy opublikowany w roku 2002, w tomie Polszczyzna a języki obce: przekład i dydaktyka, pod redakcją Władysława Chłopickiego, Język a komunikacja 4.2. Kraków: Tertium; 9-17. 


\section{Bibliografia}

Białostocki, Jan (1988) „Sztuka i świat wartości”. [W:] Maria Poprzęcka (red.) Sztuka i wartość. Materiały XI Seminarium Metodologicznego Stowarzyszenia Historyków Sztuki. Warszawa: Zakład Wydawnictw Sztuka Polska; 3-11.

Tazbir, Janusz (2000) „Jeszcze jeden skarb...”. Biuletyn Informacyjny Biblioteki Narodowej 4/2000; 46-50 [pobrane $\mathrm{z}$ http:// bn.org.pn.biulet_04_2000a.pdf, 1.12.2000

Tchórzewska-Kabata, Halina (red.) (2000) More Precious Than Gold. Treasures of the Polish National Library. (tłum.) Janina Dorosz, Philip Earl Steele (cytowana wg numeracji stron z dopiskiem „A”). Warszawa: BN.

Tchórzewska-Kabata, Halina (red.) (2000) Nad złoto droższe. Skarby Biblioteki Narodowej. Warszawa: BN. 